Cranfield School of Management

Cranfield Institute of Technology

Cranfield Bedford MK43 OAL England

Telephone National Bedford (0234) 751122

International +44234751122

Telex 826559 CITMAN G

Telefax $(0234) 751806$

\title{
Cranfield
}

1402621622

\section{SWP 15/93 A POSITIVE POLICY? CORPORATE PERSPECTIVES ON REDUNDANCY AND OUTPLACEMENT}

\author{
NOELEEN DOHERTY, PROFESSOR SHAUN TYSON and CLAIRE VINEY \\ Human Resource Group
}

The Cranfield School of Management Working Papers Series has been running since 1987, with approximately 350 papers so far from the seven academic groups of the School: Enterprise; Finance, Accounting and Economics; Human Resources; Information Systems; Marketing and Logistics; Operations Management; and Strategic Management. Since 1992, papers have been reviewed by senior members of faculty before acceptance into the Series. A list since 1991 is included at the back of this paper.

For copies of papers (up to three free, then $£ 2$ per copy, cheques to be made payable to the Cranfield School of Management), please contact Mrs Val Singh, Research Administrator, at the above address.

Copyright: Doherty, Tyson and Viney, 1993

ISBN 1859050158 


\author{
A Positive Policy ? \\ Corporate perspectives on Redundancy and Outplacement
}

Noeleen Doherty, Shaun Tyson and Claire Viney

\begin{abstract}
The management of the job loss situation is becoming of central importance to top management and human resource executives in the current climate of redundancy. The current nature of severance packages and the provision of outplacement may be interpreted as a move towards normative practices within the policy making of many UK organisations. This paper reports on the results of a recent survey of over 600 UK organisations. The survey covered organisational perspectives on redundancies and the use of outplacement in the event of redundancy. The results indicated a change in corporate values in the 1990's. There appearcd to be a move towards normative practices in the management of redundancy and in particular in the use of outplacement as a moderator of the potentially detrimental impact of the redundancy situation.
\end{abstract}




\section{Downsizing, Rightsizing, Redundancy and Lay-offs}

The UK is in the most serious recession since 1945 and many organisations are under pressure 'to restructure and reorganise in order to remain competitive. Downsizing and rightsizing are euphemistic terms which are all too familiar in todays business vocabulary. Reorganisation, closure of parts of businesses and delayering of management have resulted in widespread job losses across all industries and in organisations of all sizes, irrespective of occupational level. Even organisations which have previously espoused 'no redundancy' policies have had to reduce their numbers and the management of change relative to reorganisation and retrenchment provides just as serious a challenge to organisations as rapid expansion. This has promoted redundancy and job loss policy formulation to centre stage for corporate boards and HR executives. In this paper we will describe how organisations are developing important elements of their HR policies to manage such change.

\section{Planning for Redundancy}

The purpose of downsizing or rightsizing may be presented as essential to make an organisation more successful, productive and competitive but the impact of redundancies on those who remain may actually inhibit this. We are already familiar with the effects of redundancy on departing employees and the problems and opportunities it brings for those leaving [2] but layoffs are traumatic for everybody involved [3] especially so if the organisation has not previously used enforced redundancy policies.

Footnote 1.: This paper is based on the results of a recent survey, sponsored by Pauline Hyde \& Associates and supported by the IOD, which covered over $600 \mathrm{UK}$ organisations from all industry types and sizes. The report entitled Organisational Perspectives on Outplacement [1] is available from the Human Resource Research Centre at Cranfield School of Management. 
Thus, the impact of the job loss situation on an organisation can be far reaching. Departing employees are subjected to considerable stress but the remaining work force can be also be 'severely affected by uncertainty and suspicion and there may be detrimental effects on customer and supplier relationships, making the organisations' external and internal relationships potentially difficult and possibly damaging.

In the event of such turbulent times it is suggested that organisations should be encouraged to implement positive policies as careful planning can help to minimise the trauma [4]. A positive policy should cover a number of issues before, during and after the event [5]. The organisation should clarify its business objectives, communicate clearly and design the downsizing programme in order to avoid the uncertainty and anxiety created by the situation. The positive results arising from a proactive approach include the organisation meeting its ethical commitment to its departing employees, encouraging remaining employees to accept the situation more readily, allaying their fears about the future, showing the organisation in a favourable light in the business community and in society in general. Therefore, planning for retrenchment and in particular planning for the impact from an human resource perspective are very important. There is evidence from the organisations' point of view that the most successful downsizings are those which are strategically thought out in terms of both the business and the human resource implications. [6]. The adoption of a positive policy in the event of redundancy can therefore be seen as a central part of an human resource management philosophy which aims to secure the organisation's long term survival.

\section{The benefits of outplacement}

The use of Outplacement, a concept imported from the US in the early 1970's, may be seen as an integral part of the downsizing plan to help implement the change with as little trauma as possible both to departing and remaining employees. Outplacement is designed to help the redundant individual with the job search process, providing practical services such as the use of 
an office and more specific help in the form of personal counselling. The initial focus of outplacement service provision was at the senior executive level. Increasingly services are

'being modified to address the needs of the non executive employees who are made redundant and outplacement provision now ranges from individual one-to-one level counselling and job search activities to group programmes where CV compilation and job search strategies are applied with groups of individuals.

\section{Outplacement in Recession}

Due to the increasing number of redundancies on a large scale in the late 1980's and early 1990 's in the UK, there has been a surge of clients for Outplacement consultancies. In the UK, the 'Outplacement industry' has grown exponentially from a $f 2$ million turnover in 1978 to over $\mathfrak{E 5}$ million in 1992, now divided among about 200 firms offering these types of services [7].

In most instances the organisations initiating the redundancies incur the cost of outplacement programmes and although we are in the midst of a major recession, outplacement services are still very much in demand. UK companies even through these financially difficult times are continuing to engage external consultants to provide services to ameliorate the detrimental impact of redundancy.

\section{Why do organisations use outplacement}

Many organisations have been forced to face redundancy situations in the past few months and a number of these have provided outplacement for departing employees. Outplacement is becoming an integral part of severance packages. Although some research has explored organisations' reasons for using outplacement [8] many aspects relating to the corporate perspective still remain unknown. 
Issues relating to the job loss situation and use of outplacement which have not so far been exposed include: corporate views on the redundancy situation, what policies have been 'instituted to deal with redundancy, how are organisations locating Outplacement services into their HR policies and practices, what do they see as the benefits, how are they evaluating the use of Outplacement and what are the future requirements of industry for outplacement services?

\section{Methodology}

A large scale survey of organisations was implemented to address these issues. The survey population consisted of companies from all industry sectors, ranging from 200 to 50000 plus employees from throughout the UK. This included users and non-users of Outplacement services. A total of 628 organisations participated in the survey (a response rate of $16.2 \%$ ), the range of organisations responding representing all industry sectors and company sizes. The survey data was obtained via a self completion questionnaire, covering the organisations' job losses, job loss policies, the effect on remaining employees, the services provided for departing employees and the use and perceptions of Outplacement services. The sample showed no systematic bias and we therefore assume the views expressed are representative of these organisations. The data was gathered over the period from September to December 1992.

\section{Corporate perspectives on job loss}

This survey, spanning a sample across all industry sectors and company sizes gave some indication of the severity of job losses in the UK. We found that $88 \%$ of the responding organisations had encountered job loss situations resulting in enforced redundancies and 57\% of the responding organisations had used voluntary redundancies to reduce their labour forces. 
We found that many organisations were planning for redundancies and in particular, were considering how they could best manage the event itself. A large number of organisations 'responding (over $86 \%$ ) had some type of formal job loss policy. This finding corresponds with another recent survey on severance practices [9] where $82 \%$ of organisations indicated that they had a formal severance policy which went beyond the statutory requirements.

\section{Policy on Outplacement}

In our survey $75 \%$ offered some form of Outplacement (internal and / or external) service to their departing employees. External outplacement services were offered by over $62 \%$ of organisations. Even in recession and for large numbers of departing employees, organisations are providing outplacement services. Given the small scale of outplacement in the 1970's, we believe that in previous years this type of caring approach from organisations would have been the exception rather than the rule. This is an indication that organisations now have normative policies and practices which include the provision of outplacement services in the event of redundancy. Is this an expression of the caring face of the 1990's ?

During the recession of the 1980's some organisations used outplacement provision for senior level employees, however this trend appears to have mushroomed in the 1990's. Many organisations are now providing outplacement as standard across all levels of employees. Now not only senior executives but bluc collar workers are being offered some type of outplacement provision. This is quite significant compared to the level of help and services being offercd to those made redundant in the 1980's. Large numbers of individuals are now being provided for and organisations are picking up the cost. The underlying philosophy for this change becomes more apparent in the reasons quoted for using outplacement and the perceived benefits accrued by organisations. 
The perceived benefits of outplacement

Outplacement "won't turn a layoff into a day at the beach but a good outplacement program can "solve a whole lot of problems" [10]. The problems which organisations perceived to be most widely addressed by the use of external outplacement were mainly of a resource nature. Organisations used external outplacement services primarily because they provided specialised expertise (20\%) and could provide the resources and the time (18\%) which were not available internally. The perceived independence of external consultants was also a major factor for $16 \%$ of responding organisations, external outplacement being perceived as more credible, professional and objective third party help for the redundant individuals.

Practical help with preparing CV's and learning job hunting skills (8\%) and specific help such as counselling $(6 \%)$ were also cited as important contributions from external outplacement services. PR was quoted by over $6 \%$ of the organisations as a reason for using external outplacement services. By offering outplacement services organisations convey the image that they are doing the best for their employees.

The Kingsland James survey [8] also cited PR as a major reason for employing external outplacement services and improvement of the company image as one of the primary objectives (7\%). In our survey the organisations indicated that this objective was met, as $56 \%$ stated that one significant impact of using external outplacement services was that they helped the external reputation of the organisation.

Other corporate reasons for using outplacement highlighted in the Kingsland James survey [8] included helping staff to obtain new employment and reducing the emotional trauma of redundancy (57\% and $22 \%$ respectively). Again the findings of our survey indicate that these objectives are met, as $93 \%$ of organisations noted that external outplacement services both 
helped the individual's career and also helped with the separation process for the individual and the organisation.

(FIGURE Reasons for using external outplacement)

\section{The 'Survivors Syndrome'}

Adopting a proactive job loss policy means taking a positive stance in the management of the situation by not only providing help for those who leave but also for those who remain. After the actual downsizing event another real problem can exist for the organisation. Research has indicated that there can be a degree of survivors guilt $[11,12]$ often termed 'survivors syndrome' among those who stay in the organisation. The reactions of the remaining employees can range from shock, animosity towards management, concern about their colleagues who have left, guilt that they still have a job, to fear about the future. This may result in the low morale, decreased confidence in the company and fragmented communication which are sometimes reported.

Ultimately any lack of trust may have a detrimental impact on the organisation's performance. Outplacement has been described as beneficial not only to those departing but also to easing the trauma for the remaining employees.

\section{Addressing the 'Survivors Syndrome'}

Over $46 \%$ of the responding organisations perceived decreased motivation among remaining employees, an indication of the potentially detrimental effects of redundancy on 'survivors'. 'Survivors syndrome' is a significant area for consideration in the light of its impact on the subsequent productivity and success of the organisation. A large number (78\%) of organisations also perceived that external outplacement had a positive impact on the maintenance of morale. 
The positive philosophy being adopted by organisations was apparent in the actions they took 'subsequent to the redundancies. As a consequence of the job losses a significant number of organisations $(42 \%)$ indicated that they had increased communications with employees and over $17 \%$ indicated that they would increase communications in the event of further job losses. Such practices as providing individuals with support through the redundancy experience and increasing communication were perceived as ways to decrease some of the impacts of 'survivors syndrome'.

However, for the majority of organisations the use of external outplacement did not appear to have longer term effects in relation to retention. The use of outplacement consultancies had no observable effect on the retention of key players or on retention in general ( $82 \%$ and $84 \%$ of respondents respectively). Although the use of external outplacement was perceived to have a positive effect on the external reputation of the organisation $(56 \%)$, this was not reflected in customer / supplier relations, $(87 \%$ of organisations reported that the use of outplacement made no observable change to customer / supplier relations).

It would seem that although organisational motives for using outplacement include its perceived ability to address survivors syndrome issues and act as an external PR exercise, the actual impact of outplacement has less longer term influence on the remaining employees or on customer relations.

This data provides some clarification as to the organisational impetus for promoting the provision of outplacement as a normative practice. There appears to be a shift in values in the HR philosophy now adopted by organisations which are driven not only by a sense of duty towards individuals but also by the desire to ensure that a good corporate image is promoted in the market place and that the subsequent success of the organisation is not adversely 
effected by the redundancy situation. This is manifested in the perception that outplacement not only helps those who leave but is also beneficial to remaining employees and to 'organisational image. There are dual motives in operation from the organisational point of view. These are not only humanitarian in nature but are also grounded in business selfinterest and our research shows that some organisations do consciously make use of outplacement as a retention and damage limitation strategy during major change.

\section{Price sensitivity to external outplacement}

Nearly a third of the organisations surveyed did not use external outplacement services because of the perceived expense. However, for those organisations that did use external outplacement services, $42 \%$ perceived the cost of the service as less than $5 \%$ of the total redundancy package and $88 \%$ indicated that the cost of outplacement accounted for less than $15 \%$ of the total cost of redundancy.

The Kingsland James survey [8] considered the perceived valuc for moncy and found that $49 \%$ of organisations felt that they were getting value for money for the One-to-One Programmes and 56\% felt that they were getting value for money for the Group Programmes. There is an obvious discrepancy here between the perceptions of cost of outplacement services and the perceived value for money. In combination with the findings of the Kingsland James report [8] this data would suggest that the discrepancy may be due to organisations perceiving the less expensive group programmes as cost effective but viewing the expenditure on the more expensive One-to-One programmes as less cost effective.

Other reasons quoted for not using outplacement services were also cost-related. In our sample $10 \%$ of organisations quoted limited numbers, and $6 \%$ the level of job as a reason for not using an external service, implying that they would provide group based, jobshop services for their more junior staff if there were sufficient numbers to justify the cost. Nearly 
one in six organisations did not use outplacement services because they felt that they had sufficient capability internally to handle the situation themselves.

The qualifications, professionalism and services offered by some outplacement agencies have recently been questioned [13] suggesting that they often do not give value for money. More businesses are now attempting to obtain feedback. Over half the organisations in our survey (57\%) evaluated the benefit of external outplacement services. The major methods of doing so were; interviews with the departing employees (84\%) and peer group feedback (60\%).

These methods of evaluation provide some feedback from the individuals who have used the outplacement services. While the Kingsland James survey [8] found that the major method for evaluating the benefits of external outplacement was through feedback from the consultancy, just over $8 \%$ of our sample evaluated the bencfits in this way.

This is a strong indication that due to the large scale use of external outplacement agencies, organisations are now looking more closely at the cost and benefits of the services by obtaining feed-back from the end users as opposed to the consultancies themselves.

\section{Changing career}

Many organisations are aware that career development is in a period of change. We are now in the age of 'knowledge workers' who are not only aware of their bargaining power in a skills based market but who are also more prepared to move to achieve career advancement. The HR philosophy of many organisations is changing to reflect the changing management of this population of people. A large number of organisations in our survey provided development reviews, succession planning and career counselling $(85 \%, 67 \%$ and $66 \%$ respectively) as standard services for their employees. The propensity for increasing internal outplacement 
type activities may be an indication of organisations expanding their internal career development services in the light of the changing demands of employees in the 1990's.

\section{The future of the outplacement industry}

In the present climate there is an almost unlimited pool of material for the outplacement industry, however we should ask whether this trend will continue. Our survey examined opinions on the types of services organisations would require in the future event of more redundancies. The predominant emphasis amongst responding organisations was a need for training. If faced with the need for redundancies again, responding organisations indicated that : training managers in successfully handling the separation interview (48\%) and training in coaching and counselling ( $48 \%$ ) would be the most beneficial services.

In British companies little or no training is given in how to handle redundancies. One survey [14] found that only $16 \%$ of people who conveyed the news had been given external advice on how to make staff redundant. There is generally a poor standard of training in British management. As managers are often ill equipped to fulfil this difficult task, training would be useful to help them perform it sensitively and appropriately. This may be one future development for outplacement consultancies to consider. Even if their prospective clients wish to undertake outplacement activities internally, the staff who are performing this work will require training.

Therefore with the changing needs of the work force and the expansion of internal outplacement programmes the future for the outplacement industry may well lie in the provision of more up-stream type services such as training and development for managers in handling the redundancy situation or the more broad based career portfolio management for the increasingly flexible careers of the future. Undoubtedly, the outplacement industry will need to review its positioning in the market place as "the 1990's may mark the coning of age, 
but with client companies and individuals demanding an increasingly professional service for their money, outplacement firns will have to prove why they are a vital component of the 'redundancy and career development process". [15]

\section{Conclusions}

It appears that many organisations are developing a more pragmatic and positive approach towards the management of redundancy and lay-offs. Policy making regarding redundancy is becoming standard practice and an integral part of the HR philosophy of many companies. Normative policies now also contain common elements of outplacement provision as standard for all levels of employees. Organisations are continuing to make use of externally provided outplacement services, mainly because of the perceived expertise and objectivity provided by consultants from outside the organisation and a number of initiatives in the provision of internally delivered services are also gaining popularity. The impetus for such a value change appears to contain elements of both a more caring attitude towards employees in parallel with a concern for bottom line results which may be affected by the way redundancies are dealt with. A planned downsizing exercise is more likely to work effectively when both sets of objectives and outcomes are considered. 


\section{References}

'1. Viney, C. and Doherty, N. Organisational Perspectives on Outplacement Survey Report published by Cranfield Human Resource Research Centre 1993

2. Tyson, S. and Doherty, N. Redundant Executive : Personality and the Job Change Experience Personnel Review Vol. 20 No 51991 pp. 3-10

3. Overman, S. The Layoff Legacy HR Magazine August 1991 pp. 29-32

4. Bunning, R.L.. The Dynamics of Downsizing Personnel Joumal September 1990 pp. 69-75

5. Weinstein, H.P. and Leibman M.S. Corporate Scale Down, What Comes Next ? HR Magazine August 1991 pp. 33-37

6. Guest, D. and Peccei, R. Employee Involvement : Redundancy as a Critical Case Human Resource Management Joumal Vol 2 No 3 Spring 1992 pp. 34-59

7. Money, P. Frontiers of Work The Guardian 8/9/1992

8. Kingsland James and Business Marketing Services Ltd (BMSL) The UK Outplacement Report 1991.

9. Woodger, J. The Final Pay-off: Severance Practice in the UK, US and Canada. Personnel Management, October 1992 pp. 30 
10. Filipczak, B. Group outplacement more than how to write a resume Training Vol 19 No 6 June 1991 pp. $45-51$

11. Brockner, J., Davy, J. and Carter, C. Layoffs, Self-Esteem and Survivor Guilt : Motivation, Affective and Attitudinal Consequences Organisational Behaviour and Human Decision Processes Vol 36 No 2, 1985 pp. 113-27

12. Brockner. J., Greenberg, J., Brockner, A., Bortz, J., Davy, J. and Carter, C. Layoffs, Equity Theory and Work Performance : Further Evidence of the Impact of Survivor Guilt Academy of Management Joumal Vol 29 No 2, 1986 pp. 373-84

13. Machan, D. Meet the Undertakers Forbes November 11, 1991 pp. 384-388

14. Lewis, C. Lost Victims of Industrial Justice Director November 1991 pp. 50-57

15. Crofts, P. Outplacement : a way of never having to say you're sorry ? Personnel Management Vol 24 No 5 May 1992 pp. 46-50 


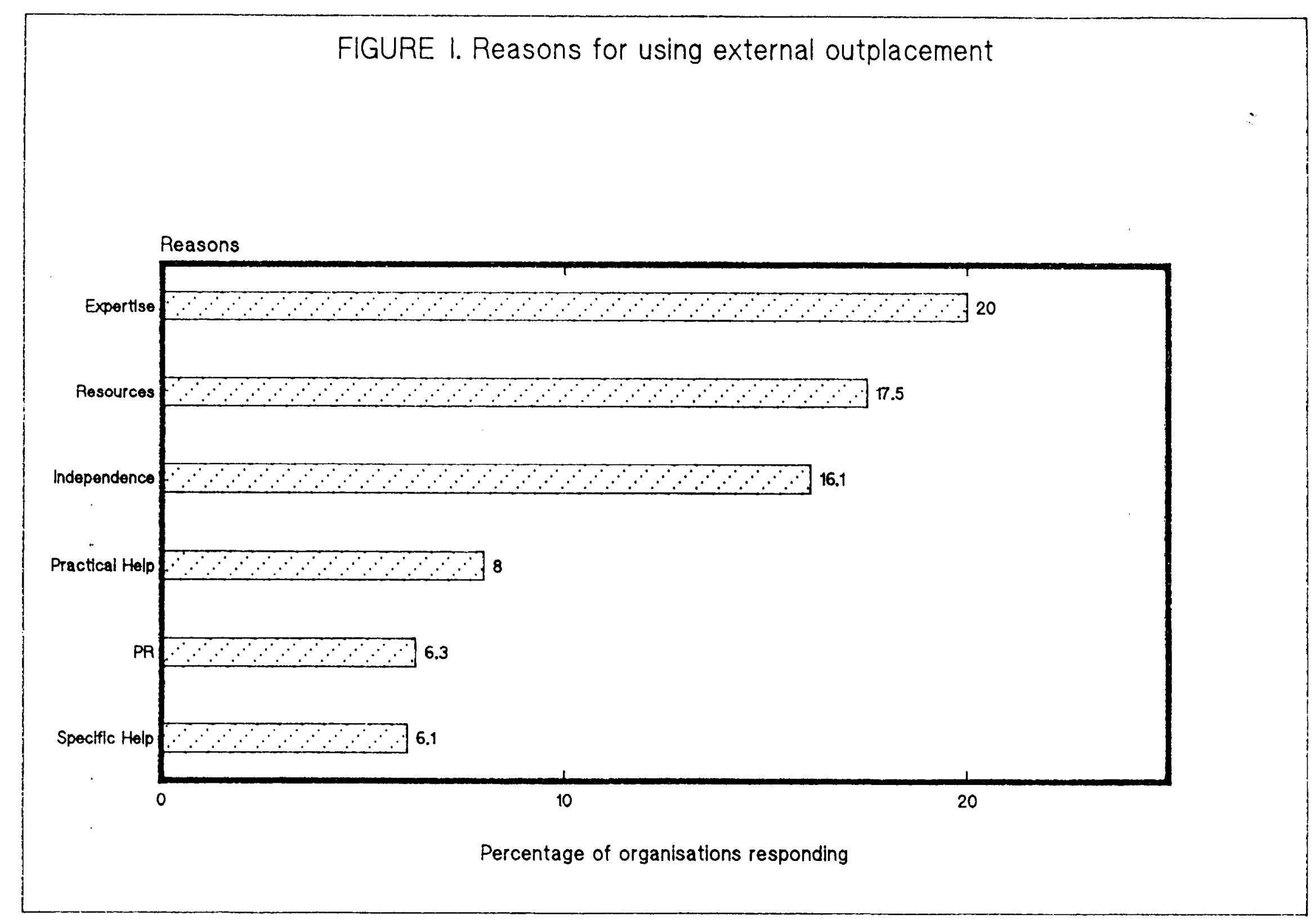




\section{CRANFIELD SCHOOL OF MANAGEMENT WORKING PAPER SERIES}

List No 5, 1991

SWP 1/91 Colin Barrow

"How Green are Small Companies? A Survey

by Cranfield School of Management"

SWP 2/91 Graham Clark

"Strategies for Product and Customer Support

- A Research Report"

SWP 3/91 David Parker

"Tackling Tax Evasion in the UK"

SWP 4/91 John McGee and Susan Segal-Horn

"Strategic Space and Industry Dynamics: The Implications for International Marketing Strategy"

SWP 5/91 Chris Brewster

"Culture: The International Dimension"

SWP 6/91 Chris Brewster and Helen Peck

"Management Changes in China and Eastern Europe: Dubious Parallels"

SWP 7/91 Keith Ward, Sri Srikanthan, Richard Neal "Marketing Investment Analysis: The Critical Success Factors for Financially Evaluation and Effectively Controlling Marketing Investment Decisions."

SWP 8/91 Andy Bytheway and Bemard Dyer

"Electronic Data Interchange: Persuading Senior Management"

SWP 9/91 Alan Warr

"Strategic Opportunities and Information Systems Management"

SWP 10/91 Alan Warr

"Bridging the Gap - Implementing Information Systems Strategies"

SWP 11/91 Alan Warr

"Mapping the Applications Portfolio onto the Projects Portfolio"

SWP 12/91 Siohhan Alderson \& Andrew Kakahadse "The Top Executive Competencies Survey - A Literature Review"

SWP 13/91 Mike Sweeney

"Determining a Technology Strategy for Competitive Advantage"

SWP 14/91 Len Holden and Helen Peck
SWP 15/91 Robert Brown \& Andy Burnett

"Do we need Enterprising Graduates?"

SWP 16/91 Ian Oram \& Clare Tagg

"Using an IS Strategic Model to give a

Strategy for Teaching IS"

SWP 17/91 Len Holden

"Employee Communications in Europe"

SWP 18/91 Susan Segal-Horn

"The Globalisation of Service Industries"

SWP 19/91 David Ballantyne

"Coming to Grips with Service Intangibles, using Quality Management Techniques"

SWP 20/91 Colin Armistead

"Resource Productivity in the Services Sector"

SWP 21/91 David Parker \& John Burton

"Rolling back the State? : UK Tax and

Government Spending Changes in the 1980s"

SWP 22/91 Simon Knox \& David Walker

"Involvement, Cognitive Structures and Brand

Loyalty: The Empirical Foundations for a

Unifying Theory"

SWP 23/91 David Ballantyne

"Internal Marketing, Collaboration and

Motivation in Service Quality Management"

SWP 24/91 Chris Brewster

"Starting again: Industrial Relations in

Czechoslovakia"

SWP 25/91 Cliff Bowman \& Gerry Johnson

"Surfacing Managerial Patterns of Competitive Strategy: Interventions in Strategy Debates"

SWP 26/91 Malcolm Harper

"Cooperatives and Other Group Enterprises:

What are the Critical Factors for Success? A

Survey of Informed Opinion."

SWP 27/91 Mike Sweeney

"The Strategic Management of Manufacturing:

From Waste to Haste"

SWP 28/91 Mike Sweeney

"How to Achieve Competitive Edge by

Simultaneous Process Engineering"

SWP 29/91 Mike Sweeney

"Towards a Unified Theory of Strategic

Manufacturing Management" 
SWP 30/91 David Ballantyne, Martin Christopher \& Adrian Payne

"The Pathology of Company-Wide Quality

Initiatives: Seven Prescriptions for Failure"

SWP 31/91 Martin Christopher, Adrian Payne \& David Ballantyne

"Relationship Marketing: Bringing Quality, Customer Service and Marketing Together"

SWP 32/91 Mike Fleming \& Joe Nellis

"The Development of Standardised Indices for Measuring House Price Inflation Incorporating Physical and Locational Characteristics"

SWP 33/91 Cliff Bowman

"Charting Competitive Strategy"

SWP 34/91 Roland Calori, Gerry Johnson \& Philippe Sarnin

"French and British Top Managers'

Understanding of the Structure and the Dynamics of their Industries: A Cognitive Analysis and Comparison"

SWP 35/91 Michael Sweeney

"Manufacturing-Led Competitiveness: Use Maths not Myths"

SWP 36/91 Robert Brown, Andrew Norton \& Bill O'Rourke

"Case Study - Beverley plc"

SWP 37/91 Malcolm Harper \& John Hailey "Management Development for Enterprise Promotion: Non-Governmental Organisations and the Development of Income Generating Enterprise"

SWP 38/91 Shaun Tyson \& Noeleen Doherty "The Redundant Executive: Personality and the Job Change Experience"

SWP 39/91 Yochanan Altman

"On Managing Volunteers - Absence of Monetary Compensation and its Implication on Managing Voluntary Organisations: The Issues of Motivation, Control and Organisational Structure."

SWP 40/91 David Parker "Privatisation Ten Years On: A Critical Analysis of its Rationale and Results."

SWP 41/91 Ian Oram

"Implications of an IS Strategic Model for IS

Development"
SWP 42/91 Shaun Tyson

"1992: An Investigation of Strategies for

Management Development"

SWP 43/91 Malcolm McDonald

"The Changing Face of Marketing"

SWP 44/91 Malcolm McDonald

"Teaching by Degrees"

SWP 45/91 Malcolm McDonald \& John Leppard "Marketing Planning and Corporate Culture"

SWP 46/91 Colin Barrow \& Andy Burnett "The Single Market and Small Growing Companies in the UK: A Survey by Cranfield School of Management"

SWP 47/91 Colin Barrow

"Key Staff Recruitment in Small Firms in the UK: A Survey by Cranfield School of Management"

SWP 48/91 Yochanan Altman "Organisational Consultancy and Clinical Psychology - The Meeting of Two Worlds"

SWP 49/91 John Hailey \& Jon Westborg

"A New Role for Development Agencies: Non-Government Organisations and Enterprise Development"

SWP 50/91 Paul Burns \& Christine Choisne "The Attitudes of Small and Medium-Sized Companies in Britain and France to the Business Environment in the First Half of $1991^{\text {" }}$

SWP 51/91 Paul Burns

"The European Market"

SWP 52/91 Shailendra Vyakarnam "The Mismatch between Academic and Practitioner Constructs of Ethics : Implications for Business Schools"

SWP 53/91 Cliff Bowman

"Managerial Perceptions of Porter's Generic Strategies"

SWP 54/91 Adrian Payne and Flemming Poufelt "Increasing the Effectiveness of Mergers and Acquisitions within the Management Consulting Industry"

SWP 55/91 John Hailey

"The Small Business Sector in Developing Economies" 
SWP 56/91 Colin Armistead \& Graham Clark

"Capacity Management in Services and the Influence on Quality and Productivity Performance"

SWP 57/91 Colin New "World Class Manufacturing versus Strategic Trade Offs"

SWP 58/91 Colin Armistead \& John Mapes

"Supply Networks and the Changing Role of Operations Managers"

SWP 59/91 Brett Collins \& Adrian Payne "Internal Services Marketing"

SWP 60/91 Andrew Myers, Mairi Bryce \& Andrew Kakabadse "Business Success and 1992: The Need for Effective Top Teams"

SWP 61/91 Malcolm McDonald "Strategic Marketing Planning: A State of the Art Review"

SWP 62/91 Malcolm McDonald "Excellent Selling can Seriously Damage a Company's Health"

SWP 63/91 Graham Clark \& Colin Armistead "After Sales Support Strategy: A Research Agenda"

SWP 64/91 Graham Clark \& Colin Armistead "Barriers to Service Quality: The Capacity, Quality, Productivity Balance"

SWP 65/91 Ariane Hegewisch

"European Comparisons in Rewards Policies: The Findings of the First Price Waterhouse/Cranfield Survey"

SWP 66/91 Andy Bailey \& Gerry Johnson "Perspectives of the Process of Strategic Decision-Making"

SWP 67/91 Collin Randlesome

"East German Managers - From Karl Marx to Adam Smith?"

SWP 68/91 Paul Bums \& Christine Choisne "High Performance SMEs: A Two Country Study"

SWP 69/91 David Parker "Ownership, Managerial Changes and Performance"
SWP 70/91 Graham Elkin (Visiting Fellow) "Socialisation and Executive MBA Programmes"

SWP 71/91 Shai Vyakarnam

"The New Europe from the Third World"

SWP 72/91 John Hailey

"Small Business Development in the

Developing World: An Overview of

Contemporary Issues in Enterprise

Development ${ }^{n}$

SWP 73/91 Paul Burns

"Training Within Small Firms"

SWP 74/91 Paul Burns \& Christine Choisne

"High Performance SMEs in Britain and

France: Strategies and Structures"

SWP 75/91 Robert Brown et al

"UK Tax Implications for the Small Business"

\section{SCHOOL WORKING PAPERS LIST NO 6, 1992}

SWP 1/92 Mike Sweeney

"How to perform simultaneous process engineering"

SWP 2/92 Paul Burns

"The Management of General Practice"

SWP 3/92 Paul Burns

"Management in General Practice: A Selection of Articles"

SWP 4/92 Simon Knox \& David Walker

"Consumer involvement with grocery brands"

SWP 5/92 Deborah Helman and Adrian Payne

"Internal marketing: myth versus reality?"

SWP 6/92 Leslie de Chernatony and Simon Knox "Brand price recall and the implications for pricing research"

SWP 7/92 Shai Vyakarnam

"Social Responsibility in the UK Top 100

Companies"

SWP 8/92 Susan Baker, Dr Simon Knox and Dr Leslie de Chernatony

"Product Attributes and Personal Values: A Review of Means-End Theory and Consumer Behaviour" 
SWP 9/92 Mark Jenkins

"Making Sense of Markets: A Proposed

Research Agenda"

SWP 10/92 Michael T Sweeney and Ian Oram "Information Technology for Management Education: The Benefits and Barriers"

SWP 11/92 Keith E Thompson (Silsoe College) "International Competitiveness and British Industry post-1992. With Special Reference to the Food Industry"

SWP 12/92 Keith Thompson (Silsoe College) "The Response of British Supermarket Companies to the Internationalisation of the Retail Grocery Industry"

SWP 13/92 Richard Kay

"The Metaphors of the Voluntary/Non-Profit Sector Organising"

SWP 14/92 Robert Brown and Philip Poh

"Aniko Jewellers Private Limited - Case Study and Teaching Notes"

SWP 15/92 Mark Jenkins and Gerry Johnson "Representing Managerial Cognition: The Case for an Integrated Approach"

SWP 16/92 Paul Burns

"Training across Europe: A Survey of Small and Medium-Sized Companies in Five European Countries"

SWP 17/92 Chris Brewster and Henrik Holt Larsen "Human Resource Management in Europe Evidence from Ten Countries"

SWP 18/92 Lawrence Cummings "Customer Demand for 'Total Logistics Management' - Myth or Reality?"

SWP 19/92 Ariane Hegewisch and Irene Bruegel "Flexibilisation and Part-time Work in Europe"

SWP 20/92 Kevin Daniels and Andrew Guppy "Control, Information Seeking Preference, Occupational Stressors and Psychological Well-being"

SWP 21/92 Kevin Daniels and Andrew Guppy "Stress and Well-Being in British University Staff"

SWP 22/92 Colin Armistead and Graham Clark
SWP 23/92 David Parker

"Nationalisation, Privatisation, and Agency Status within Government: Testing for the Importance of Ownership"

SWP 24/92 John Ward

"Assessing and Managing the Risks of IS/IT Investments"

SWP 25/92 Robert Brown

"Stapleford Park: Case Study and Teaching Notes"

SWP 26/92 Paul Burns \& Jean Harrison "Management in General Practice - 2"

SWP 27/92 Paul Burns \& Jean Harrison

"Management in General Practice - 3"

SWP 28/92 Kevin Daniels, Leslie de Chernatony \& Gerry Johnson

"Theoretical and Methodological Issues concerning Managers' Mental Models of Competitive Industry Structures"

SWP 29/92 Malcolm Harper and Alison Rieple "Ex-Offenders and Enterprise"

SWP 30/92 Colin Armistead and Graham Clark "Service Quality: The Role of Capacity Management"

SWP 31/92 Kevin Daniels and Andrew Guppy "Stress, Social Support and Psychological Well-Being in British Chartered Accountants"

SWP 32/92 Kevin Daniels and Andrew Guppy

"The Dimensionality and Well-Being Correlates of Work Locus of Control"

SWP 33/92 David Ballantyne, Martin Christopher, Adrian Payne and Moira Clark

"The Changing Face of Service Quality Management"

SWP 34/92 Chris Brewster

"Choosing to Adjust: UK and Swedish Expatriates in Sweden and the UK"

SWP 35/92 Robert Brown, with Peter Cook et al "Goldsmiths Fine Foods - Case Study and Teaching Notes"

SWP 36/92 Mike Sweeney

"Strategic Manufacturing. Management: Restructuring Wasteful Production to World Class" 
SWP 37/92 Andy Bailey \& Gerry Johnson

"An Integrated Exploration of Strategic

Decision-Making"

SWP 38/92 Chris Brewster

"European Human Resource Management:

Reflection of, or Challenge to, the American

Concept"

SWP 39/92 Ute Hanel, Kurt Volker, Ariane Hegewisch and Chris Brewster

"Personnel Management in East Germany"

SWP 40/92 Lawrence Cummings

"Logistics goes Global - The Role of Providers and Users"

SWP 41/91 Roger Seaton \& Martin Cordey-Hayes "Interactive Models of Industrial Technology Transfer: A Process Approach"

SWP 42/92 Susan Segal-Horn

"The Logic of International Growth for Service Firms"

SWP 43/92 Mike Sweeney

"Benchmarking for Strategic Manufacturing Management"

SWP 44/92 Paul Burns

"Financing SMEs in Europe: A Five Country Study"

SWP 45/92 Robert Brown

"The Graduate Enterprise Programme - Has it been Worthwhile?"

\section{CRANFIELD WORKING PAPERS} List No 7, 1993

SWP 1/93 John Mapes

"The Effect of Limited Production Capacity on Safety Stock Requirements for Periodic Review Inventory Systems"

SWP 2/93 Shai Vyakarnam \& Alison Rieple "Corporate Entrepreneurship: A Review"

SWP 3/93 Cliff Bowman \& David Faulkner "Pushing on a String: Uncertain Outcomes from Intended Competitive Strategies"

SWP 4/93 Susan Baker \& Mark Jenkins

"The Role of Values in the Design and Conduct of Management Research: Perspectives on Managerial and Consumer
SWP 5/93 Kevin Daniels, Leslie de Chernatony \& Gerry Johnson

"Validating a Method for Mapping Managers' Mental Models of Competitive Industry Structures"

SWP 6/93 Kevin Daniels \& Andrew Guppy "Occupational Stress, Social Support, Job Control and Psychological Well-Being"

SWP 7/93 Colin Fletcher, Ruth Higginbotham and Peter Norris

"The Inter-Relationships of Managers' Work Time and Personal Time"

SWP 8/93 Mike Sweeney

"A Framework for the Strategic Management of both Service and Manufacturing Operations"

SWP 9/93 Colin Armistead and Graham Clark "The 'Coping' Capacity Management Strategy in Services and the Influence on Quality Performance"

SWP 10/93 Ariane Hegewisch "Equal Opportunities Policies and Developments in Human Resource Management: A Comparative European Analysis"

SWP 11/93 Paula Stanley "Service to the Courts: The Offender's Perspective"

SWP 12/93 Mark Jenkins

"Thinking about Growth: A Cognitive Mapping Approach to Understanding Small Business Development"

SWP 13/93 Mike Clarke

"Metro-Freight: The Automation of Freight Transportation"

SWP 14/93 John Hailey "Growing Competitiveness of Corporations from the Developing World: Evidence from the South"

SWP 15/93 Noeleen Doherty, Shaun Tyson and Claire Viney

"A Positive Policy? Corporate Perspectives on Redundancy and Outplacement " 